\title{
DEVELOPMENT OF LOCAL GOVERNMENT AS AN ALTERNATIVE TO HYPER CONCENTRATION OF THE POWER IN RUSSIA
}

\author{
Vladimir A. Sologub ${ }^{1}$, Irina A. Hasheva ${ }^{2}$
}

\begin{abstract}
Local self-government existed throughout the history of Russia, regardless of the successive forms of government. Despite some transformations in the municipal sphere, certain objectives of Russia's municipal reform have not been realized. This article describes the reasons for permanent reform of local government in the plane of standard and legal character, the financial and economic limitations of the municipality, and the low activity of self-organization of citizens. Moreover, authors provide the results of a public poll regarding the reform of the local self-government and give an assessment of the results of the reforms undertaken and define the existing problems and prospects of developing local government as objectives of this research. Authors concluded that the existing system of local self-government needs modernization and should be based on certain strategy and tactics involving historical approach and analysis of current socioeconomic conditions for future progress.
\end{abstract}

UDC Classification: 353.1, 353.8; DOI: http://dx.doi.org/10.12955/cbup.v6.1248

Keywords: centralization, local self-government, the hyper-concentration of power, political culture, decentralization, the 'power vertical', competence, autonomy.

\section{Introduction}

Centralization and local self-government, about which the prominent Russian historian, Vasily Klyuchevsky wrote at the beginning of 21 st century, is a problem for any state or country. However, in Russia, the problem tends to constantly return to a state of insolubility with highly unfavorable conditions for local self-government. Theoretically, the tendency to participate in affairs at the local level could reverse this insolubility and bring the situation out of the vicious circle of hyperconcentration of power.

In one form or another, local self-government has existed throughout the history of Russia, regardless of the successive forms of government. The nature of relations in the system of Russia's state administration was, for centuries, determined by the autocratic nature of the supreme power. In the legal worldview of the Russians, each body, i.e., each office, was seen as a representative of the Governor (monarch, king, Emperor, General Secretary, and President), who was responsible only to the Governor. The limits of the exercise of power were determined, not by law and the legislative system, but by the political will of the first person. This explained the practical impossibility of carrying out a clear division of powers in the system of public administration, both in 'power vertical' and 'power horizontal'. To paraphrase the words of Lenin, the local government has been the 'fifth wheel in the cart' of the Russian state machine. A complex set of external and internal causes exist. Hence, to understand the specifics of forming and developing local self-government, one requires knowledge of the cultural and historical peculiarities of Russian civilization.

The geographical position of the country had a huge effect on the course of Russian history. An academic of the Imperial St. Petersburg Academy of Sciences, on the separation of Russian language and literature, Solovyov (1998, p.31), noted that the special geographical position at the junction of Europe and Asia has led to Russia becoming a type of shield "between the two hostile races of the Mongols and Europe". Hence, the constant military threats to the country from the West and the East, as a consequence, meant an urgent need for authoritarian centralization of power. The abovementioned factors determined the role, place, and nature of the Russian state power, conditioned by the needs of self-defense and self-preservation. Altogether, this presupposed the absence of formal legal restrictions of the supreme power. As Vernadsky (1993, p.48) noted, "autocracy and serfdom were the price that the Russian people paid for their national self-preservation".

\footnotetext{
${ }^{1}$ Department of state and municipal management; South-Russia Institute of Management - branch of Russian Presidential Academy of National Economy and Public Administration (70/54, Pushkinskaya St., Rostov-onDon, 344002, Russian Federation). E-mail: svvol65@mail.ru

${ }^{2}$ Department of state and municipal management; South-Russia Institute of Management - branch of Russian Presidential Academy of National Economy and Public Administration (70/54, Pushkinskaya St., Rostov-onDon, 344002, Russian Federation). E-mail: ihasheva@mail.ru
} 
The type of state power formed led to the emergence of a special political culture. The traditional and usual powers for Western European countries that are balanced between state and local (public) interests have not found their embodiment in the Russian political and socio-cultural spheres. Unlike European civilization, the Russian state and its institutions have become an absolute, with sacral features. State institutions have become the starting point of all historical development of people's life. The people helped all forces in the dispensation of the 'Fatherland', but not their own initiative and their unquestioning obedience carried community-wide gravity for the common good. This is the historical significance of the autocratic power that gave Russia a strength beyond that of any single European country, before which, the representative institutions had to disappear.

As Shamkhalov (2011) points out, such an outcome testifies to the fact that the institute of local selfgovernment in Russia has its roots in national local self-government. Such a system has placed state interests at the forefront. In these circumstances, people are not just disengaged from the political life of the country and passive, they are devoid of autonomy and without initiative, experiencing a type of awe at the power of people at all levels of management

These factors contributed to the establishment of centralized power. However, history presents many striking examples of the radical changes in the attitude of the population regarding power in times of crisis and with the weakening of the state system (e.g., during turmoil or revolution). It is noted that there are two main trends in the development of the Russian statehood. The first presupposed a powerful authoritarian centralized power, unlimited by law. The centralized weakening and the strengthening of decentralization led to the predominance of the second trend, the main features of which were the collapse of state institutions, the loss of control levers, the slide into chaos, and the 'fragmentation' of Russia. Decentralization, accompanied by the separation of powers and decisionmaking, was incompatible with the basic principles of the Russian state system. As a result, academic Leonov (2017) noticed the numerous plans that were organized for an effective mechanism of local self-government but which had no chance of success.

Nevertheless, despite the pronounced dominance of these trends, it is noted that at certain historical stages, the institution of local self-government became a constituent element in the organization of power. It was impossible to govern a Russian state that had numerous ethnic groups and peoples settled on the basis of a unified model of local self-government, land, social, and other affairs. Government structures at various times used different options for forming the administrative system and self-government in the territorial entities on the basis of the political situation and the effectiveness of state self-government. In view of the resistance of the bureaucracy inertia and social mobility of the general population, the reformist elite had to delegate part of the authority of the supreme power to the 'field', to liberate the initiatives of citizens. Hence, attempts to develop an effective model of local self-government have been and continue to be one of the main components of the modernization projects aimed at radically reforming the Russian state and society.

On one occasion, the French sociologist Crozier (1972) noted that

The main resources in the reform of the state are, first of all, human resources. Having emphasized the development and use of these resources, it would be possible to obtain quite unexpected results, since these resources can become the main lever of modernization of the state. (p.14)

Any complex system involves decentralization of management functions where each level of hierarchical management has obligations, resources, and powers to fulfill, and bears a certain responsibility for the results of decisions. At the same time, management is understood as exogenous, i.e., an external influence entering the system, and self-government as an endogenous, i.e., produced within the system. Each social formation has its own specific combination of governance and selfgovernance.

Regarding the pre-reform Soviet period, the local government was carried out by public authorities that were local councils represented by the people's deputies. Local councils resolved all issues of local importance on the basis of national interests and the interests of citizens of the council's territory. They implemented the decisions of higher state bodies, directed the activities of lower councils, and managed economic and socio-cultural construction in the subordinated territory. 
There was a principle of 'power vertical', where the higher council could assess issues of competence of the lower council and could cancel the lower council's decision. Identifying that Councils had never been self-governed at any level, Solzhenitsyn (1998) noted the following:

They as a form of self-government played an edge, not insignificant, role in the process of real governance. The Soviet model, as opposed to local self-government, has become a product, part, and tool of the command-administrative, Hyper-centralized system and at the same time served as a democratic camouflage. (p. 190)

In the conditions of total control by the state, the institutions of local self-government had no chance of self-realization and became appendages of the existing management system.

At the same time, the idea of self-government as an element of public administration was formally incorporated into the state system. Party leaders of the Soviet period faced the same administrative problems as their predecessors. There was the inefficient management of exclusive administrative approaches with centralized command, the presence of inertia in the population, and, as a consequence, a lack of initiative among the general public. Throughout the Soviet period, the country's leaders were cautious not to go beyond the existing ideology with attempts to reform the territorial self-government. Starting with the restructuring of society for democracy as proclaimed by the central government, the forming and developing of the system of local self-government entered a new phase.

\section{Prerequisites for Forming Local Self-Government in the Post-Soviet Period}

Local self-government, as a decentralized form of management, involves the autonomy of local authorities. They act as bodies of local self-governing territorial communities. Local self-government in practice is characterized by three main elements:

- Broad powers that do not overlap with those of other levels of government;

- Sufficient economic resources available to local authorities; and

- Development as a democratic institution of civil society. This is determined first by the accessibility of benefits of municipal administration and the possibility of direct participation of the population in managing the territory's affairs (the 'direct forms of democracy').

The revival of interest in a local self-government in Russia was connected with the general democratic transformations initiated by the political movement, Perestroika. In Russia, at the time of the beginning of fundamental changes, all such elements were in their infancy and needed development. Both political and economic motives served as direct stimuli for the revival of local self-government in the post-Soviet period. The process of forming and approving local self-government institutions in Russia as bodies capable of competing on equal terms with those of the state in solving a whole range of problems could not but encounter several difficulties.

First, there was the incompleteness of forming institutions of civil society, the market economy, and municipal property. Then, an overall decline occurred in the living standards of the general population. Other problems included unstructured local budgets with limited income base and acute confrontation of various political forces involving the Executive and legislative branches of government.

The situation in the Russian economy has since changed. The mechanism for making decisions and the allocation of resources for the economy underwent substantial modifications. According to Minakir (2017), introducing mechanisms of economic freedom at the micro level (for enterprises and associations) with the transfer of decision-making rights about productive resources to users, often enterprises with a resource shortage, led to the decentralization of management functions. This change dismantled the fundamental principle of 'power vertical', which was developed according to the central scenario and at the expense of the central resources.

Under the new conditions, the Federal center declared it would be impractical to direct the state to manage and reproduce all social processes involving the new tasks and detailed regulation of economic activities of enterprises and organizations. This approach generally changed the perception of opportunities and tools needed to overcome the crisis phenomenon in the regions and required the transitioning to a new paradigm of governance and self-government at the regional level. It also meant focusing on the inevitable integration of market regulators to stimulate local self-government in Russia. Thus, managing the economic development of the district or city would need to be the most important task of local authorities. However, realizing this in such a complex post-Soviet transitive 
period was challenging. There was the choice of either the decision-making influence, which was inherent in the Soviet management system that was considered untenable, or the indirect methods that could be used as levers to create the conditions for effective use of the municipal, private, or jointstock property.

Of interest to research scientists, is the empirical analysis and research and practical synthesis from sociological monitoring of the problems of local government. This includes the use of expert assessments and content analyses. For example, a well-known sociologist and corresponding member of the Russian Academy of Sciences, Toshchenko (1997), noted that:

Problems related to the development of industry, construction, agriculture, should not care about and worry local authorities - it is the competence of owners, businessmen, business leaders. But the reality is (and not without the influence of past experience) that local governments cannot withdraw from this sphere. Moreover, they are under pressure from both outside and inside for any attempts not to deal with these problems. In other words, the local government was in a paradoxical position-from the point of view of the theory it had to leave the sphere of direct decision-making and management, but from the point of view of reality, local governments could not do it. (p.110)

According to the research conducted by Toshchenko (1997), the authorities during the nineties were largely deliberating on a planned economy and, with difficulty, learned the meaning of market relations. In addition, an average Russian person, less burdened with the knowledge of the forms and directions of improving public and political management, had no clear idea of the place, purpose, or functions of local government as an independent authority that could oppose the power of the state. This led the general population of the 1990s to view the actions of local authorities in specifically dealing with these problems as ineffective (Table 1).

\begin{tabular}{|c|c|c|c|}
\hline $\begin{array}{l}\text { Name } \\
\text { problems }\end{array}$ & $\begin{array}{l}\text { Actions were } \\
\text { are effective }\end{array}$ & $\begin{array}{l}\text { There were actions, } \\
\text { but had no effect }\end{array}$ & No actions were taken \\
\hline unemployment & 10.2 & 64.8 & 21.5 \\
\hline poverty & 5.2 & 52.8 & 36.8 \\
\hline housing problem & 12.8 & 59.0 & 24.8 \\
\hline municipal services & 19.8 & 58.4 & 17.7 \\
\hline social assistance & 23.9 & 59.5 & 11.4 \\
\hline
\end{tabular}

In addition, the reform of local self-government, based on a set of factors, was carried out 'from above'. In the conditions created in Russia, the state could not withdraw from local affairs, because the state distanced itself from the demands at that time and began to limit the reforms in other spheres of society. The unpreparedness of Russian citizens for self-organization and a low regard in the mass consciousness of the value of self-government meant that developing local self-government, based on social actions 'from below', was problematic.

Naturally, the state was faced with the task of developing forms of legal regulation in the field of local self-government, which, on the one hand, would not violate the rights and interests of the people of the Federation, and on the other, allowed Federal protection of the basic principles of local selfgovernment. At the same time, local self-government on a new basis was approved not from 'below', i.e., on the initiative of the local population with interests in the viability and capacity of the newly created power body, but rather from 'above', i.e., by the will and attitude of representatives of the central government and power structures of the Federation.

One result in this direction, which marked the beginning of reforming the Soviet model of local selfgovernment on the canons of Western democracy, was the adoption of the law of the Russian Federation of July 6, 1991 № 1550-1 'On local self-government in the Russian Federation'. It is in this law that the term 'local self-government' began circulation. Former local councils were 'assigned' the status of local self-government and given certain autonomy, although, in practical terms, they continued to fulfill the competencies of the former government. These 'new' authorities often independently determined their powers, forms, and instruments of interaction with public authorities, 
to solve problems arising in the course of a crisis. The result of this stage was the understanding that forming an effective institution of local self-government is a lengthy process requiring high-quality regulatory and legal regulation and accumulation of experience and appropriate financial support. The representative body of local self-government was entitled to approve the local budget, the expenditure of funds, and the establishment of local taxes and fees, through submission to and approval by the head of the local self-government (head of administration). The head of the administration also had the right to convene meetings of the representative body of local self-government and approve its decisions. All other issues were decided solely by the head of administration.

Since 1996, the federal law of August 28, 1995, №154, 'On General Principles of Organization of Local Self-Government in the Russian Federation', has been fully in force. This law defines the legal, organizational, financial and economic foundations of the local self-government system. It is believed that with the enforcement of this law that local self-government began to form in the country. With this law, the country has developed a noticeable diversity of systems of sub-regional public administration and local self-government, with a predominance of a tendency to increase the number of regions that used a single-level (mainly 'district-urban', rarely-settlement) system of municipal management. The law, for the first time, provided a list of issues of local importance, which included 30 items. Previously, many questions from the list fell within the jurisdiction of the state.

In the same year, 1996, the European Charter of local self-government was signed and then later ratified and approved by the Federation Council in 1998. It created the prerequisites for forming the institutional foundations of local self-government in a single democratic process in the country and was a logical process in the socio-political transformations. However, by the early 2000s, it became apparent that the legal structure of the federal law №154 provided no full-scale solution to these problems (particularly in rural settlements) and made it necessary to develop a new institutional concept for the next stage of the municipal reform in the country. The separation of powers with a new authority caused a funding resource problem. The intraregional decentralization and adoption of federal law №154 led to an increase in the expenditure of local budgets, among other municipal issues, as the municipalities were obliged to maintain the social facilities transferred to their local level. With a lack of budgetary resources, the reforms were a large burden resting with the local level of government.

Under these conditions, by 2003, the prerequisites for the implementation of a new stage of the municipal reform were ready. The process had identified shortcomings and implemented a number of recommendations concerning both the reasonableness of regulatory legislation and the financial security of local self-government. Hence, it was necessary to discuss reducing the hyper-concentration of power at the Federal level.

\section{Permanent Reforms of Local Self-Government}

The conceptual basis of the reform for local self-government in Russia assumed the autonomy of local authorities from state power, which was generally consistent with the decentralization trends in most countries of the world in recent decades. However, in Russia, these trends conflicted with the processes of centralizing the power, which required the preservation, reproduction, and strengthening of the subordinate local authorities, on the one hand, and the gradual accumulation of resources at the higher levels of power on the other. The results of implementing municipal reforms have been somewhat controversial and failed to provide the volume and quality of services that the population needed in an economically developed state at the local level.

According to Professor Zotov (2017), further development of local self-government in the near future may be determined by the choice of one of the two most realistic scenarios:

1. Further centralization, strengthening of the 'power vertical', covering all levels of public administration, including urban and rural settlements. Similar development of events bears essential risks, in particular: excessive concentration of power resources at regional administrations; delegation of political responsibility of the central power in case of mass discontent of inhabitants during the possible social cataclysms caused by actions of the regional and local authorities; redistribution of property, property withdrawal from municipal level to the regional level; limited socio-economic basis of local self-government reform; 
weakening of incentives for local self-organization. In view of the above-mentioned points, the implementation of such a scenario is seemingly impractical.

2. Complex change of the existing system of power relations due to successive transformations in the direction of reasonable decentralization. This approach transfers the vertical state power to the level of regions, and in some cases to the level of districts. Local self-government, implemented at the first level of power in settlements and cities, would be independent, primarily in affairs with the regional authorities. Stimulation of activity 'from below' acts as a system-forming factor for overcoming crisis phenomena, and emergence and expansion of points of growth at the local level.

The current period of forming local self-government in Russia and the reorganization of public power involves the search for a perfect model of local self-government functioning. This is one that would ensure the optimization of the 'power vertical' and act in unity with the Russian Federation. Permanent municipal reform, revealing the depth of the systemic crisis of municipal governance, brings to the fore the issues of understanding the prospects of Russian local self-government while maintaining adherence to the underlying constitutional ideals.

The need for further improvement of local self-government prompted the federal center to initiate a new large-scale reform of local self-government for adopting the federal law of October 6, 2003, №131: 'On General Principles of Local Self-Government in the Russian Federation'. This document served as the basis for the beginning of fundamental changes in the system of local self-government in Russia. The reform was aimed at bringing this level of power closer to the population, to its interests and needs, as well as making it full, independent, and responsible for a certain range of issues and authorities within the framework of a single policy aimed at solving complex problems of the country's development. From this viewpoint, much has been achieved including the approval of the municipal boundaries, identifying and assigning revenue sources for the budgets of the municipalities, adopting statutes of municipalities, and finalizing elections for local governments. According to the legislation, the entry of enforcement was postponed until January 1, 2009, and this availed the possibility of introducing new provisions on developing local self-government during the special transitional period.

Meanwhile, another round of legislative changes in 2008 allowed for assignment of property between the levels of government. Federal and regional properties were transferred to the property of municipalities where relevant to solve issues of local importance. A two-tier system of municipal government resulted in a separation of ownership between the municipal areas and member populations, where the conditions of vesting local governments had separate state powers.

The next stage of the municipal reform started in Russia between 2014-2015 and was initiated by changes in legislation. It is known that the amendments that began the next stage of municipal reform were brought in with the federal law №131 in May 2014 and are better known as the federal law of May 27, 2014 №136. This stage was unexpectedly one of the most ambitious and complex due to its composite nature. First, there was a 'vertical' reform to redistribute powers between the federal, regional, and municipal authorities. Second, there was a 'horizontal' redistribution of responsibilities within the settlements between the Duma, the head of the city, and the city manager. Thus, change in the system of power relations between various authorities of local and regional levels was accompanied by a change in the system forming local authorities. Such a situation with selfgovernment is fraught with a number of potentially problematic situations. These start with the mechanisms of coordinating key candidates at the elite level to the potential change in the social base of local self-government, due to possible rejection by the ordinary population of the proposed innovations. It also involves narrowing the impact of these processes on the competence of municipalities regarding the sustainable development of specific settlements.

The analysis showed that the latest reforms significantly reduced the competence assigned to the municipal sphere as a whole, regardless of the level of municipalities. It also expanded the powers of the region and the possibility of their intervention in the competence of local self-government. Apart from the legislation that emphasized the framework, that is, the liberating nature of the proposed changes and the choice of several proposed models, the reforms narrowed the self-governing base. There was a decrease in the number of powers of municipalities at the 'grass-roots' level and 
significant changes pertaining to the formation of local governments. In fact, there was a noteworthy redistribution of powers between municipal and regional (federal) authorities in favor of the latter, and local governments were further integrated into the 'power vertical'.

The situation especially changed for rural municipalities. The previous version of federal law №131 had a common concept of 'settlement'. However, the new version separated the types of municipalities into 'urban settlements' and 'rural settlements', and assigned them a different number of competencies. Where there was no change in the number of competencies for the urban settlements, those of rural settlements were significantly reduced, decreasing to 13 competencies, with the remaining competencies transferred to the municipal districts. The federation then obtained the right to award additional competencies to the rural settlement, transferring them from competencies of the municipal districts.

As a result, the burden on the regional self-government bodies, which, on the one hand, were assigned the competence to manage issues of local importance in rural settlements, and on the other, increased dependence on regional authorities. In addition, as previously noted, for rural and urban settlements, as well as for municipal districts, the procedure for forming local self-government bodies was remarkably changed. Direct elections of the heads of these municipalities were replaced by those by a representative body of the municipality from among the candidates submitted by the Competition Commission.

Today, the head of administration is not elected by the population. Deputies from among the candidates are approved in advance by a special commission that consistently includes representatives of higher authorities, i.e., from regional or federal. Thus, in practice, implementing the proposed innovations has led to a weakening of the institutional position of the local self-government in regards to local and regional policy, a strengthening of control in regional authorities, and in fact, a considerable reduction in the number of municipal practices. Thus, the line of demarcation separating the current Russian local self-government from the remaining 'vertical' local authorities of the Soviet period remains unclear.

This is indicated by empirical studies by Russian scientists into the problems and prospects of permanent reform in local self-government. For example, Uskova et al. (2016) noted that the proportion of heads of municipalities positively assessing the results of extreme changes implemented in the framework of municipal reform was decreasing (Table 2).

Table 2: Distribution of answers to the question 'How do you assess the results of measurements carried out in the framework of the reform of the local self-government in relation to your municipality?' as a percentage

\begin{tabular}{|c|c|c|c|c|c|c|c|c|c|}
\hline \multirow{3}{*}{$\begin{array}{l}\text { Option } \\
\text { answer }\end{array}$} & \multicolumn{9}{|c|}{ Municipal unit } \\
\hline & \multicolumn{3}{|c|}{$\begin{array}{l}\text { Municipal } \\
\text { District }\end{array}$} & \multicolumn{3}{|c|}{$\begin{array}{l}\text { City } \\
\text { Settlements }\end{array}$} & \multicolumn{3}{|c|}{$\begin{array}{l}\text { Rural } \\
\text { Settlements }\end{array}$} \\
\hline & 2006 & 2011 & 2014 & 2006 & 2011 & 2014 & 2006 & 2011 & 2014 \\
\hline positive & 57.1 & 23.0 & 46.7 & 77.8 & 49.9 & 69.2 & 63.5 & 35.9 & 37.4 \\
\hline the situation hasn't changed & 42.9 & 38.5 & 33.3 & 0.0 & 43.8 & 15.4 & 21.2 & 35.3 & 31.3 \\
\hline negative & 0.0 & 38.5 & 20.0 & 22.2 & 6.3 & 15.4 & 15.3 & 28.8 & 31.3 \\
\hline
\end{tabular}

Thus, the heads of urban and rural settlements are negatively related to the changes. This is probably because, in the early stages of the municipal reform, the heads of municipalities had significant positive expectations, supported by measures of state support, but a few years later the goals of forming local self-government as a truly independent level of power were not achieved.

Similar results from their studies were obtained by Zazulina (2017), who noted the reflections by the heads of municipal districts on the latest changes in legislation regarding the integration of local governments in the 'power vertical' were positive. However, $44 \%$ of the representatives of local selfgovernment did not approve of it (Table 3). A negative assessment to date on reducing the scope of competence of rural communities was expressed by the representatives of the village government $(60 \%)$ and $39 \%$ of the representatives of the district government. In general, according to Zazulina (2017), only about $20 \%$ approved these parts of the reform. Also, the attitude towards these aspects of 
the reform accumulated into the main protest stances and emerges as the most significant problem in the present stage of forming domestic local self-government.

\begin{tabular}{|c|c|c|c|}
\hline $\begin{array}{l}\text { Relation to separate innovations } \\
\text { in the legislation on local government }\end{array}$ & All & Area & Settlement \\
\hline \multicolumn{4}{|l|}{ Big integration with a power vertical } \\
\hline I approve & 37 & 67 & 30 \\
\hline I don't approve & 38 & 11 & 44 \\
\hline There is no answer & 25 & 22 & 26 \\
\hline \multicolumn{4}{|c|}{ Reduction of the sphere of competence of the rural settlement } \\
\hline I approve & 18 & 17 & 18 \\
\hline I don't approve & 56 & 39 & 60 \\
\hline There is no answer & 26 & 44 & 22 \\
\hline \multicolumn{4}{|c|}{ Change of the principles of formation of local governments (cancellation of selectivity) } \\
\hline I approve & 22 & 56 & 14 \\
\hline I don't approve & 62 & 33 & 69 \\
\hline There is no answer & 16 & 11 & 17 \\
\hline
\end{tabular}

Consequently, it is concluded that innovations in the law, in particular, the abolition of elections and the reduction of competencies of rural settlements, have not met with unequivocal support among local authorities, as many provisions have led to increased concentration of power at higher levels. The analysis of the factors hindering effective management of municipal development shows that many managers consider the deficit of their own sources of income, dependence on regional authorities, bureaucratic problems of public authorities, limited powers in the field of development of the municipality, and the lack of effective cooperation with public authorities, including the coordination of policy documents (Table 4).

Table 4: The factors preventing effective management of municipal development (\%)

\begin{tabular}{|l|l|l|l|}
\hline Factor & $\begin{array}{l}\text { Municipal } \\
\text { educations }\end{array}$ & $\begin{array}{l}\text { Municipal } \\
\text { district }\end{array}$ & $\begin{array}{l}\text { City } \\
\text { Settlements }\end{array}$ \\
\hline Deficiency of own sources of income & 84.2 & 100.0 & 93.0 \\
\hline Insufficient financial support from the state & 63.2 & 84.6 & 76.2 \\
\hline Dependence on regional government & 31.3 & 72.7 & 61.6 \\
\hline Passivity of the local population & 37.5 & 66.7 & 58.7 \\
\hline $\begin{array}{l}\text { Lack of balance of interests of the population, Business and } \\
\text { power in the process of territory development }\end{array}$ & 27.8 & 61.5 & 58.7 \\
\hline Bureaucratic procrastination of organs state power & 29.4 & 41.7 & 51.4 \\
\hline $\begin{array}{l}\text { Imperfection of legislative and regulatory framework at the } \\
\text { state level }\end{array}$ & 47.1 & 54.5 & 47.5 \\
\hline $\begin{array}{l}\text { Limited powers in the field of } \\
\text { economic development of the municipality }\end{array}$ & 61.1 & 9.1 & 46.8 \\
\hline Lack of effective cooperation with state authorities & 35.3 & 25.0 & 43.4 \\
\hline $\begin{array}{l}\text { The lack of coherence of program documents (at the regional } \\
\text { and federal level), aimed at the development of municipalities }\end{array}$ & 55.6 & 18.2 & 40.7 \\
\hline Source: Authors & & \\
\hline
\end{tabular}

The data show that there was a steady decrease in the share of local revenues for budgets collected in the territories and an increase in the share of targeted subsidies from the higher level of the budget system. This financial dependence means that the region independently decided on the need for equity in solving territorial problems without considering the position of municipalities. This shows that systemic work in this area of reform had not yet been developed. The functional dependence of local authorities, as well as their financial incompetence, contributed to the statehood of local selfgovernment. In fact, municipal administrations have become territorial administrations of the constituent entity.

Thus, the results of the assessment indicate grounds to assert that the representatives of administrative elites do not generally accept the constitutional notion of dividing the state and municipal powers, as 
sufficiently and consistently embodied in the Federal law, №131. Local authorities are mainly subordinate to central government bodies, yet have partial freedom in their activities. However, on this issue, the trend of mixing the authorities and, therefore, the state and local powers, indicates that the local self-government has limitations and possibly is purely a formality. The reform of local selfgovernment is slow and falls short of the desired results. Local self-government bodies are increasingly being integrated into the 'power vertical' of the state while there are increasingly fewer opportunities for their own initiatives.

The above findings would indicate that no local self-government, by a true definition, exists in Russia. Instead, there exists a lower level of state power. The underlying reasons for this interpretation derive from the evolution of the state mechanism, the expansion of the state bureaucracy, the historical limitation of the rights of local self-government, and the entirely formal mode of existence of its bodies. Further reasons are the lack of a clear and systematic policy of the state towards local selfgovernment in recent years. At this stage, the problem of the effectiveness of local self-government is resolved by its inclusion in the 'power vertical'. These factors reinforce the drift of local selfgovernment from the sphere of civil society towards an increasing merger with the state administrative 'power vertical'. Furthermore, local authorities are largely deprived of incentives and opportunities for effective local self-government and motivation of the population to participate in self-government.

\section{Conclusion}

The complex and contradictory historical path of the forming and subsequent development of local self-government has had a considerable effect on the current situation due to the Soviet political traditions that continue to affect the local self-government culture today. As a result, there was a situation where the European model, in its form, had demonstrated a completely different effect because of the influence of the peculiarities of Russian administrative, legal, and political practices. The historical experience of Russian self-government has had somewhat similar concepts and problems to the modern institute of local self-government. In fact, the relations between these two entities in the Soviet period of 'region-district (city)-village Council (settlement)' was reproduced in several of the country's territories. Hence, a better devolution of power to local governments may avoid unnecessary over-concentration of power at the state level and overloading of the central government with local affairs. The main problem with implementing reforms of local self-government is not about choosing between centralization and decentralization, but rather establishing a reasonable balance between these. This response involves a balance based on the comparative historical approach, corresponding to the conditions of the country's development and the functional characteristics of all levels of government. Clearly, there is the need to implement a set of measures in the field aimed at improving effective governance and effecting permanent reforms of local self-government. Finally, there is a need for further well-considered modernization of the existing system of local selfgovernment, and therefore a need to determine the strategy and tactics for future progress.

\section{References}

Crozier M. (1972). La societe bloquée. Revue française de sociologie. P. 13-22.

Leonov S.N. (2017). Problem results and the prospects of reform of local government in Russia, Spatial economy, 3:107-132.

Minakir P.A. (2017). The Far East and Transbaikalia on the eve of reform: concepts of entry into the market, Spatial economy, 1:17-51.

Shamkhalov M.A. (2011). Prerequisites of formation of local governments in the Russian Federation, the Power. 12: 49-53

Soloveyv S.M. (1998). History of Russia since the most ancient times. Compositions: In 18 books by the Prince 1: T.1:

Nature of the Russian state area and its influence on history, Electronic resource [Access mode: free] URL:

http://militera.lib.ru/common/solovyev1/01_01.html

Solzhenitsyn A.I. (1998). Russia in a collapse. Hl. in prince: "Local government" - M., Publishing house: Russian way, $187-$ 192.

Toshchenko Zh.T., Tsvetkova G.A. (1997). Local government: formation problems (experience of the sociological analysis), Sociological researches, 6:109-119.

Uskova T.V., Bukhvald E.M., Voroshilov N.V. (2016). Local government in Russia: results and prospects of reforms, Problems of development of the territory, 5:159-175.

Vernadsky G. V. (1993). Remarks on the legal nature of the serfdom, Homeland, 3:48-53.

Zazulina M. R. (2017) of Feature of realization of reform of local government in communities of regional and settlement levels, the Siberian philosophical magazine, 3:112-123.

Zotov V.B. (2017.) The prospects of development of local government in modern Russian conditions, Municipal academy, 1: 6-20. 